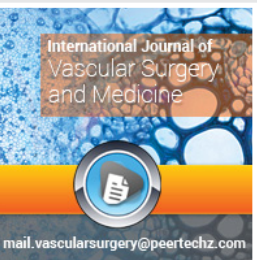

Medical Group

\title{
International Journal of Vascular Surgery and Medicine
}

Nwafor IA ${ }^{1 *}$, Nwafor $\mathrm{MN}^{2}$, Eze JC', Ezemba $\mathrm{N}^{1}$, Chinawa $\mathrm{JM}^{3}$, Nzewi $\mathrm{OC}^{4}$ and $\mathrm{Ngene} \mathrm{Cl}^{5}$

'Senior lecturers $t$ and honorary consultant cardiothoracic surgeons, University of Nigeria, Enugu Campus, Nigeria

${ }^{2}$ Deputy Director Pharmacist in charge of intensive care unit, UNTH, Ituku/Ozalla, Enugu, Nigeria ${ }^{3}$ Senior lecturer and honorary consultant paediatric cardiologist, University of Nigeria, Enugu Campus, Nigeria

${ }^{4}$ Chief Consultant cardiac surgeon, Belfast, UK. ${ }^{5}$ Senior Registrar, Department of surgery, UNTH, Ituku/Ozalla, Enugu, Nigeria

Dates: Received: 12 December, 2016; Accepted: 31 January, 2017; Published: 02 February, 2017

*Corresponding author: Nwafor IA Doctor; National Cardiothoracic Center of Excellence (NCTCE), Department of Surgery, University of Nigeria, UNTH, Enugu Campus, Nigeria, Tel: +2348037784860 ,

E-Mail: igbochinanya2@yahoo.com

Keywords: Perioperative; Open Heart Surgery (OHS) Thromboelastography; Platelet Function Analyzer

https://www.peertechz.com

\author{
Research Article
}

Open Heart Surgery: Management

of Nonsurgical Bleeding in the

Peri-Operative Period; $3^{1 / 2}$-Years

Institutional Experience

\section{Abstract}

Background: Excessive perioperative bleeding remains a major complication following open heart surgery, resulting in increased morbidity and mortality of some patients in our institution. A study of the principal causes of excessive nonsurgical haemostatic perioperative bleeding, clinical evaluation, treatment and preventive strategies is justified.

Objective/Aim: To characterize the causes of bleeding in patients with hemorrhage that did not require re-exploration and assess the impact on the patient outcomes from different causes of nonsurgical bleeding preoperatively.

Materials and Methods: For a period of $3^{1 / 2}$ years (March 2013 - February 2016), the National Cardiothoracic Center of Excellence, UNTH, Ituku/Ozalla, Enugu, Nigeria, partnered with different foreign cardiac missions (USA, UK and India) for the performance of open heart surgery. The case files of the patients managed in the envisaged period were retrieved and analyzed using SPSS, version 4.0. The data analyzed were patients' demographics, the total number of open heart surgery cases, the number that had perioperative nonsurgical bleeding, clinical detection strategies, treatment and preventive modalities as well as the outcome.

Results: During the period, a total number of 78 cases of open heart surgery (OHS) were done. There were 43 males and 35 females, with a ratio of approximately 4:3. The youngest age was 5 months and the oldest was 74 years, with a mean of 1.0. Out of these 78 cases, a total of 7 patients had perioperative nonsurgical bleeding, giving a percentage of $9 \%$. 3 patients were noticed intraoperatively in the operating room (OR) while 4 were noticed postoperatively in the intensive care unit (ICU). Treatment included preoperative preventive strategies, the use of tranexemic acid or aprotinin, fresh frozen plasma (FFP) or fresh whole blood, platelet concentrate and additional doses of protamine, when incomplete reversal of heparin was the cause.

Conclusion: Detection of the cause(s) of nonsurgical bleeding without Thromboelastography or platelet function analyzer can be quite challenging in our environment. Applying appropriate pharmacologic agents among other interventions can reduce allogenic blood requirements with their attendant complications.

\section{Introduction}

Patients undergoing open heart surgery are at the risks of excessive perioperative bleeding, both surgically and nonsurgical leading to increased useage of allogeneic blood and haemostatic blood products with attendant complications [1]. Although this patient population represents a relatively small proportion of surgical patients, cardiac surgery consumes about $20 \%$ of the available blood supply in the United State [2], with similar number reported worldwide [3,4].
The principal causes of nonsurgical haemostatic perioperative bleeding are a pre-existing undetected bleeding diathesis which may include failure to recognize and stop patients on anticoagulant medications some days prior surgery and making sure that the coagulation panel, like the international normalized ratio (INR), activated prothromboplastin time (aPTT) and platelet counts are within normal level. Cardiopulmonary bypass (CPB) is known to activate four primary plasma proteins \{factor IX, factor IX, prekallikrein and high molecular weight kininogen $(\mathrm{HWK})\}$, through contact with foreign surfaces of 
the pump. The activated factor IX activates the complement system, intrinsic coagulation and the neutrophils. Furthermore, foreign surface contact of the pump also activates the fibrinolytic system and platelet in addition to causing platelet dysfunction. Coagulation abnormality arising from massive blood loss or inadequate doses of heparin can result in disseminated intravascular coagulopathy (DIC) and consumption of coagulation factors. Understanding the haemostastic changes occurring in the perioperative period, especially during the cardiopulmonary bypass is crucial in developing new strategies for the management of excessive perioperative bleeding [5]. Drug useages, especially aprotinin, tranaxemic acid, desmopressin and increasingly recombinant VIIA are being used prophylactically and therapeutically to stop bleeding [5]. The use of point of care tests like thromboelastography and platelet function analyzer has allowed for more detailed assessment of various steps of haemostasis [6]

It is important that the surgical and anaesthetic teams realize that many pre-existing so called mild bleeding disorders, eg., VWD (Von Willibrand Disease) are clinically silent from day-to-day and only manifest at times of haemostatic stress such as surgery [7]. One of the key points in minimizing perioperative blood loss is an index of suscipicion and the identification of patients who at increased risk of bleeding [1]. Those undergoing moderate or high risk procedures like open heart surgery should have a PT, APTT and platelet count performed [8]. Simple measures may mean that patients on aspirin is stopped 7 days prior to surgery, other NSAIDS, 2 days and warfarin at least 3-4 days prio-, commencing postsurgery when haemostasis is secured [9]. Alternatively, if anticoagulation is required patients could be switched over to either intravenous unFractionated heparin for prosthetic heart valves or subcutaneous low molecular weight heparin (LMWH).

Perioperative haemostatic changes have been widely studied in complex procedures of open heart surgery, using CPB. Haemostatic activation occurs as a result of the hyperadrenergic state induced by the stress of surgical stimulation. Hyperfibrinolysis is a feature of open heart surgery $[8,9]$. Consumption of coagulation factors, platelets and physiologic anticoagulants, from bleeding/haemodilution is a feature of the complex procedures in open heart surgery leading to a decrease in platelet count, FVIII, vWF, antithrombin and protein $\mathrm{C}$ as well as platelet dysfunction perioperatively [10,11-14]. In fact bleeding time as a measure of impaired haemostasis has a strong linear correlation with the length of bypass and degree of hypothermia [15]

\section{Materials and Methods}

For a period of 3 years (March 2013 - February 2016), the National Cardiothoracic Center of Excellence, UNTH, Ituku/Ozalla, Enugu partnered with different foreign cardiac missions (USA-VOOM, UK-Save a Heart Nigeria and IndiaInnova $\mathrm{CCH}$, Hyderabad) for the performance of open heart surgery. A retrospective study was performed to that effect. The case files of the patients managed during the period were retrieved and analyzed using SPSS version 4.0. The data analyzed were patients' demographics, the total number of open heart surgery cases, the number that had perioperative nonsurgical bleeding, clinical detection strategies, treatment and preventive modalities as well as the outcome. Those that had surgical bleeding that required intraoperative resuturing for their treatment were excluded from the study.

\section{Results}

During the period, a total number of 78 cases of OHS were done. There were 43 males and 35 females, with a ratio of approximately 4:3. The youngest age was 5 months and the oldest was 74 years, with a mean of 37.8 . Out of these 78 cases, a total of $7(8.97 \%)$ patients had excessive perioperative nonsurgical bleeding. 3(3.85\%) were noticed intraoperatively in the OR while $4(5.13 \%)$ were noticed postoperatively in the ICU. Treatment methods included preoperative preventive strategies like stopping aspirin or other similar drugs few days before operation and making sure that coagulation profile (PT, INR, aPTT) were within normal limit. Others were the use of tranexemic acid or aprotinin, FFP or fresh whole blood, platelet concentrate and additional doses of protamine, when incomplete reversal of heparin was the cause.

\section{Discussion}

Expected and unexpected events occur frequently in patients undergoing open heart surgery. Such expected event for instance, is bleeding which could be surgical or nonsurgical. When there is excessive perioperative bleeding that is nonsurgical, it is usually unexpected and it beholves on the managing team to quickly identify the fault and address it so as to have a good outcome. Bleeding after open heart surgery can be broadly divided into 2 groups: surgical (unrecognised bleeding vessels, anatomosis, or suture lines) and nonsurgical bleeding caused by coagulopathy [16]. Factors influencing both can be further broken down into those occurring preoperatively, intraoperatively and postoperatively. A thorough understanding of these factors is necessary to reduce bleeding. This is a desirable clinical goal, because excessive bleeding postoperatively is associated with morbidity and mortality [17].

In this study, 78 patients had OHS in the envisaged period (Figure 1). In this study, the male to female ratio is 3:1. The numbers that had OHS in our institution ranged from $0-10$ to $71-80$, with those in the age range of $41-50$ with $19.23 \%$ being the highest.

The general nonsurgical bleeding tendency in the early postoperative phase can be attributed to mainly 5 factors: viz, platelet function and count, excessive fibrinolysis, heparin rebound and deficiencies in clotting factors as well as hypothermia. Risks of bleeding increases further if the patient remains in $\mathrm{CPB}$ for more than 90 minutes. The average $\mathrm{CPB}$ time in our patients with bleeding was more than four hours. The longer a patient's blood is exposed to the mechanical artificial surfaces, the greater the likelihood that platelets malfunction and trigger the clotting cascade leading to bleeding. Preoperative evaluation excluding bleeding diathesis, patients on anticoagulants or antiplatellets and polycythaemic cyanotic 
patients will impact favourably in reducing postoperative nonsurgical bleeding [18].

In this study, out of the 7 patients studied with excessive perioperative bleeding, those with valve procedures and total correction for TOF, constituted the highest with $33.33 \%$ each. They were followed by those with pericardiectomy and valve procedure and valve procedure with resection of left atrial appendage with $8.33 \%$ each. In all of them CPB time was prolonged averaging 6-8 hours (Table 1). Two of the 7 patients were on aspirin preoperatively which was stopped 4 days prior to surgery. In other study, it was found that periopertive bleeding complications in cardiac surgery can have multiple aetiologies. Invasiveness of the procedure, induced hypothermia, extended use of $\mathrm{CPB}$, and increasing age, were the major reasons for increased blood loss and the higher incidence of blood transfusions [19].

In (Table 1), The intraoperative variables showed parallelism among intraoperative estimated blood loss, intraoperative requirement of packed red blood cell (PRBC), use of local haemostatic agent like surgical or $\mathrm{Mph}$, transfusions of fresh frozen plasma (FFP) and platelet concentrate and cardiopulmonary bypass time. The greater the estimated blood loss (EBL), the more the PRBC required with the attendant morbidity and mortality, except in the case of a Jehovah witness, who underwent pericardiectomy with valve procedure. His large EBL was not corrected with PRBC, and this led to patient death. In a similar study, Christensen et al., demonstrated that $22 \%$ of patients with excessive perioperative haemorrhage died compared with $6 \%$ of patients without excessive perioperative bleeding [20].

The central mediator in the process of clot formation is the generation of thrombin which acts to convert fibrinogen to fibrin, the basic building block of clot. To prevent thrombosis during $\mathrm{CPB}$, heparin is administered, although some degree of thrombin formation and subclinical clot formation does occur in the presence of adequate heparinisation. All our patients had prebypass heparin achieving an ACT of more than 480 seconds before institution of cardiopulmonary bypass. In prolonged CPB, it can result in consumptive coagulopathy and excessive nonsurgical bleeding. Average CPB time in the index patients were prolonged, averaging 7 hous/420 mins Patients undergoing open heart surgery with cardiopulmonary bypass has increased microvascular bleeding by numerous mechanisms. Exposure of blood to extracorporal circulation including hypothermia leads to impaired haemostasis and excessive bleeding on account of activation of intrinsic and extrinsic pathways with resultant thrombin and fibrinolytic activity [18].

The postoperative period, (Table 2), Showed variables such as chest tube output, PRBC requirement some hours in the immediate postoperative period, platelets requirement and intensive care unit median stay as well as 30 day mortality. There were correlations in the chest tube out and PRBC, FFP and platelet requirements. There was also increased morbidity and 30 day morality was statistically notable in patients with
Percentages

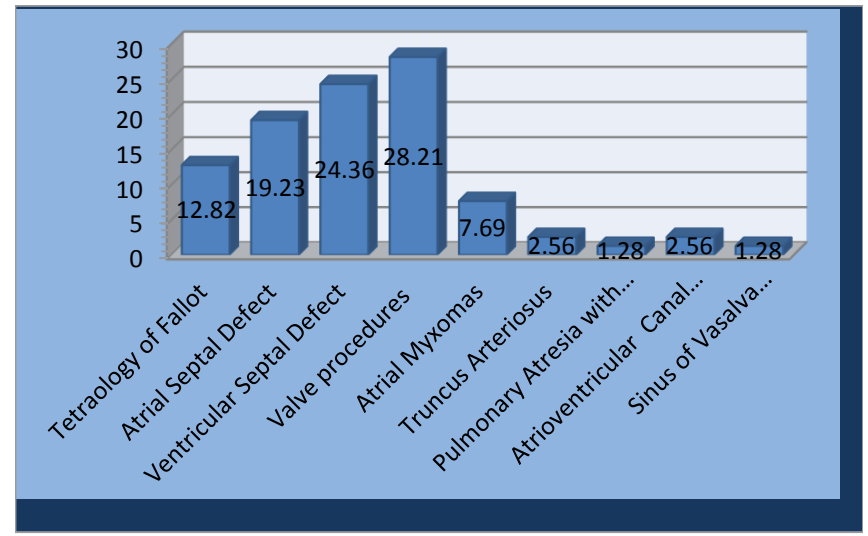

Indications for open heart surgery

Figure 1: Indications for the Open Heart Operations

Table 1: Patients that had excessive perioperative nonsurgical bleeding.

\begin{tabular}{|c|c|c|c|c|c|}
\hline$s / n$ & Types of procedure & $\begin{array}{c}\text { Number } \\
\text { of } \\
\text { patients }\end{array}$ & $\begin{array}{c}\text { CPB } \\
\text { time } \\
\text { (mins) }\end{array}$ & $\begin{array}{c}\text { Degree of } \\
\text { hypothermia } \\
\text { oC) }\end{array}$ & $\begin{array}{l}\text { Use of ell } \\
\text { saver? }\end{array}$ \\
\hline 1 & Valve procedures & 3 & $300-480$ & $32-34$ & Yes \\
\hline 2 & $\begin{array}{l}\text { Pericardiectomy }+\mathrm{V} / \\
\text { procedure }\end{array}$ & 1 & 480 & 34 & Yes \\
\hline 3 & R-atrial myxoma excision & 1 & 420 & 32 & \\
\hline 4 & $\begin{array}{l}\text { Valve procedure + resection } \\
\text { of L-atrial appendage }\end{array}$ & 1 & 480 & 34 & Yes \\
\hline 5 & Total correction for TOF & 1 & 480 & $32-34$ & No \\
\hline Total & & 7 & & & \\
\hline
\end{tabular}

Table 2: Postoperative variables in the affected patients.

\begin{tabular}{|c|c|c|c|c|c|c|c|}
\hline Variable/Patients & P1 & P2 & P3 & P4 & P5 & P6 & P7 \\
\hline CTTD output $24 \mathrm{hrs}$ postop(ml) & 470 & 600 & 750 & 500 & 600 & 450 & 600 \\
\hline $\begin{array}{l}\text { PRBCs(units) } \\
\text { Pt received } 1-2 \text { units } \\
\text { Pt received }>3 \text { units }\end{array}$ & $\begin{array}{c}\text { Yes } \\
-\end{array}$ & yes & $\begin{array}{c}- \\
\text { yes }\end{array}$ & - & $\begin{array}{c}- \\
\text { yes }\end{array}$ & Yes & yes \\
\hline ICU platelet 24 hrs postop(units) & 1 & 2 & 2 & 1 & 2 & 1 & 2 \\
\hline ICU FFP 24 24hr postop(units) & 1 & 3 & 3 & 2 & 3 & 1 & 2 \\
\hline ICU median stay & 4 & 1 & 1 & 5 & 4 & 5 & 6 \\
\hline 30 day mortality & - & 1 & 1 & - & - & - & 1 \\
\hline
\end{tabular}

Key: $\mathrm{P}=$ patient, $\mathrm{CTTD}=$ chest tube thoracic drainage, $\mathrm{ICU}=$ intensive care unit.

higher output, degree of blood and blood product requirements $[21,22]$.

During the $3^{1 / 2}$ year period, a total of 78 cal cases of open heart surgery were done (Figure 1) out of which 12 had perioperative nonsurgical bleeding, representing $10.3 \%$. They were identified by excluding surgical bleeding and isolating the haemolysis in the nasogastric tube and the urine as well as derangement it the haemostatic parameters such as APPT, platelet count, clotting factors and PCV. These patients were managed with blood (red cell) and blood products (platelet concentrate and FFP) (Table 3). Correction of hypothermia, and reinfusion of protamine, when adjudged that heparin was 
inadequately reversed, were used in the management. Also used was traxanemic acid (CRASH 1 \& 2) [23,24] and aprotinin. Desmopressin was not used as it was not available. There was also no availability of recombinant FVII (rFVII) in our institution. The off-label use of rFVII in cardiac surgery has increased exponentially in the past 12 years, primarily to treat refractory hemorrhage during or after cardiac surgery $[25,26]$. Anticipated use of recombinant-activated factor VII is used in preventing postoperative bleeding in cardiac surgery [26].

Out of the 12 patients managed, 5 died representing $41.7 \%$. Of the 5 patients that died, 3 were females while 2 were males, giving a male to female ration of $2: 3$, representing $1.7 \%$ to $25 \%$ respectively. In two of the demised patients, there was associated constrictive pericarditis as a comorbidity. This not only prolonged the bypass time but also provoked a lot of tissue thromboplastic on account extensive tissue dissection, all leading to consumptive coagulopathy (Figure 2,3).

\section{Conclusion}

Excessive perioperative Non-Surgical bleeding following open heart surgery is a haemostatic failure from various causes and its management requires a multidisciplinary approach. Intraoperatively and postoperatively, exclusion of surgical causes is important and presence of complex point of care tests like platelet function analyzer, Thromboelastography and rFVII assay will aid in rapid diagnosis of the specific cause(s).

Table 3: Intra-operative Variables in the affected patients

\begin{tabular}{|c|c|c|c|c|c|c|c|}
\hline Variables/Patients & P1 & P2 & P3 & P4 & P5 & P6 & P7 \\
\hline CPB time & 6 & 5 & 7 & 8 & 8 & $71 / 2$ & 6 \\
\hline $\begin{array}{c}\text { Intraop EBL(ml) } \\
\text { Intraop PRBC(units) }\end{array}$ & 450 & 600 & 550 & 400 & 750 & 1200 & 950 \\
\hline $\begin{array}{c}\text { Intraop use of surgicel/ } \\
\text { microporous polysaccharide } \\
\text { haemosphere haemostat (degree) }\end{array}$ & + & +++ & ++ & + & +++ & ++++ & +++ \\
\hline \begin{tabular}{c} 
Intraop FFP (units) \\
\hline Intraop platelets(units)
\end{tabular} & 2 & 2 & 2 & 2 & 3 & 3 & 3 \\
\hline
\end{tabular}

Key: $\mathrm{p}=$ patient, $\mathrm{EBL}=$ Estimated Blood Loss, $\mathrm{PRBC}=$ Packed Re Blood Cell, FFP = Fresh froze Plasma.

\section{(Number)}

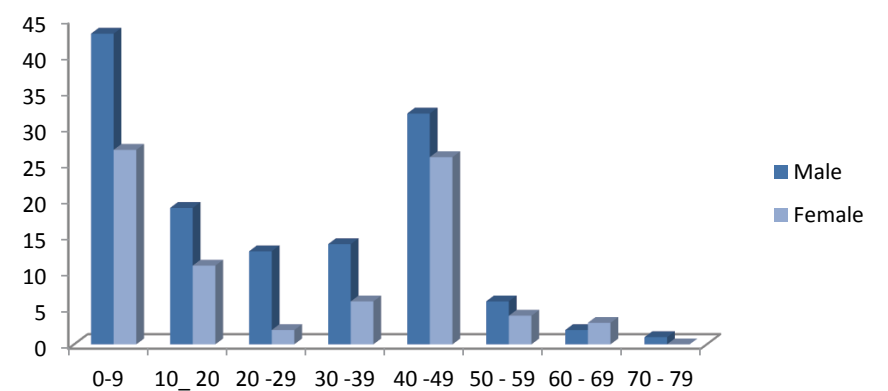

Figure 2: Sex Distributions of Patients
Percentages

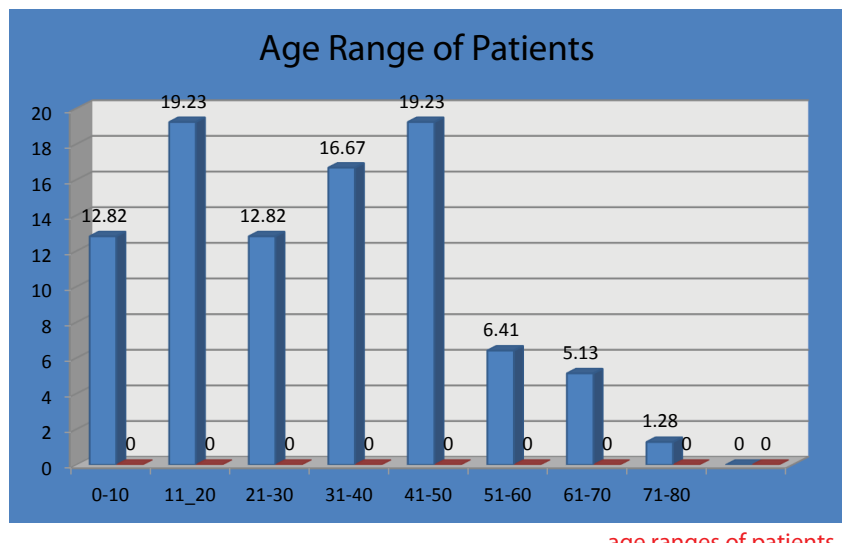

age ranges of patients

Figure 3: Age range of patients.

\section{References}

1. Speiss BD (2002) Transfusion and outcome in heart surgery. Ann Thorac Surg 74: 986-987. Link: https://goo.gl/zb0Jvw

2. Wells AW, Mounter PJ, Chapman CE, Stainsby D (2002) Wallis JP Where does blood go? Prospective observational study of red cell transfusion in north England. BMJ 325: 803. Link: https://goo.gl//zlH53

3. Stover El, Siegel LC, Parks R, Levin J, Body SC et al. (1998) Variability in transfusion practice for coronary artery bypass graft persiss despite national consensus guidelines. A 24-institution stdudy. Institutions of the multicenter study of perioperative Ischemia Research Group. Anaesthesiology, 88: 327333. Link: https://goo.gl//t6LOk

4. Hebert PC, Fergusson DA (2004) Do the transfusion get to the heart of the matter? JAMA, 292:1610-1612. Link: https://goo.gl/cbRH4j

5. Handrick HG, Meijer K, de Wolf Jt, Klompmaker IJ, Porte RJ et al. (2001) Reduced transfusion requirement by recombinant factor VIIA in autologous liver transplantation, a pilot study. Transplantation. 71: 402-405. Link: https://goo.gl/UDVZ60

6. Koh MBC, Hunt BJ (2003) Management of perioperative bleeding. Blood Review 17: 179-185. Link: https://goo.gl/TQkwro

7. Francis $\mathrm{CW}$, Kaplan $\mathrm{KL}$, Haemorrhagic problem in the surgical patient. Bleeding and Thrombosis In: Holffman R, Benz BJ, Shattil SJ, Furis B, Cohen $H J$, Stilberstein LE, MacGlare $P$, eds. Haematology Basic Principles and Practice. Churchill Livinstone 2000 p: 2381-2391.

8. Blood transfusion task force. Transfusion for Massive Blood Loss. Clin Lab Haematol 1998, 10: 265-73.

9. Segal H, Hunt BJ (2000) Aprotinin pharmacological reduction of perioperative bleeding. Lancet, 355: 1289-1290. Link: https://goo.gl/m83QxN

10. Royston D, Bidstrip BP, Taylor Koll, Spspford RN (1987) Effects of aprotinin or need for blood transfusion after repeat open heart surgery. Lancet 8572 : 1289-1291. Link: https://goo.gl/Ypu4eR

11. Hunt DJ, Pamatt RN, Segel H, Sheikh S, Kallis P et al. (1998) Activation of coagulation and fibrinolysis during cardiothoracic operations. Ann Thorac Surg 65: 712-718. Link: https://goo.gl/n9Q5IC

12. Mammen EF, Koets MH, Washington BC, Wolk LW, Brown JM et al. (1985) Haemostasis Changes during cardiopulmonary bypass surgery. Semin Thromb hemost 11: 281-292. Link: https://goo.gl/FQRy32

13. Woodman RC, Harker LA (1990) Bleeding complications associated with cardiopulmonary bypass. Blood 76: 1680-1697. Link: https://goo.gl/eG03Ri 
14. Gelb AB, Roth RI, Levin J, London MJ, Noall RA et al. (1996) Changes in Blood Coagulation during and following cardiopulmonary bypass. Lack of correlation with clinical bleeding. Am J Clin Pathol 166: 57-79. Link: https://goo.gl/j2IAHy

15. Colman RW (1995) Haemostatic Complications of cardiopulmonary bypass. Am J Haematol 48: 267-272. Link: https://goo.gl/koPWMI

16. Boistlar MD, Lane DA, Philippou H, Esnouf MP, Sheikh S et al. ( 1993) Mechanisms of Thrombi generation during Surgery and cardiopulmonary bypass. Blood 82: 33-50. Link: https://goo.gl/gWhEX0

17. Hall T, Sines J, Spotintz A (2002) Haemorrhage related reexploration following open heart surgery, the impact of preoperative and postoperative coagulation testing. Cardiovasc Surg 10: 146-153. Link: https://goo.gl/zE95xR

18. Ascione R, Williams S, Lloyd CT, Sundaramoorthi T, Pitsis AA et al. (2001) Reduced postoperative blood loss and transfusion requirement after beatingheart coronary operations: a prospective randomized study. J Thorac Cardiovasc Surg 121: 689-696. Link: https://goo.gl/te4NT4

19. Gorlinger K, Shore Lesserson L, Dirkmann D, Harke AA, Rahe-Mayer N et al. (2013) Management of haemorrhage in cardiothoracic surgery. J cardiothoracic Vasc Anaesth 27: 20-34. Link: https://goo.gl/6a0dFN

20. Brucner BA, Blan LN, Rodriguez L, Suarez E, Ngo UQ et al. (2014) Microporous polysaccharide hemosphere absorbable hemostst use in cardiothoracic surgical procedures, Journal of Cardiothoracic Surgery 9: 134. Link: https://goo.gl/no1GtO

21. Christensen M, Krapf S, Kempel, A, Avon HC (2009) Costs of excessive postoperative haemorrhage in cardiac surgery. J Thorac-Cardiovasc Surg 138: 687-693. Link: https://goo.gl/InBHw9

22. Levy JH, Depotis GJ (2008) Transfusion and haemostasis in cardiac surgery Transfusion 48: 15. Link: https://goo.gl/u47Nb4

23. Lapar D, Crosby I, Ailewadi G, Gad N, Choi E et al. (2013) Blood conservation is associated with improved outcome and reduced cost after cardiac surgery. J Thorac Cardiovasc Surg 145: 796-803. Link: https://goo.gl/Bolu0S

24. CRASH-2 Trial Collabotors, Shakur H, Roberts I, Bautista R, Caballero J et al. (2010) Effects of tranexamic acid on death, vascular occlusive events, and blood transfusion in trauma patients with significant haemorrhage(Crash-2): a randomized placebo -controlled trial. Lancet 376: 23-32. Link: https://goo.gl/YxBgVM

25. CRASH-2 Trial Collaborators, Roberts I, Shakur $\mathrm{H}$ Afolabi A, Brohi K et al. (2011) The importance of early treatment with tranexamic acid in bleeding trauma patients: an exploratory analysis of the CRASH-2 randomized controlled trial The Lancet 377: 1096-1101.e2. Link: https://goo.gl/cc1Zq9

26. Agarwal V, Okonta KE, Lal PS (2012) Recombinant-activated VII in the paediatric cardiac surgery: Single Center experience. Afr J Paediatr Surg 9: 193-197. Link: https://goo.gl/IJd3JY 